\title{
Some ultrastructural observations of a thraustochytrid (Protoctista, Labyrinthulomycota) from the clam Ruditapes decussatus (Mollusca, Bivalvia)
}

\author{
C. Azevedo, L. Corral \\ Department of Cell Biology, Institute of Biomedical Sciences and IMAR - Institute of Marine Research, University of Oporto, \\ Largo A. Salazar no. 2, P-4050 Porto, Portugal
}

\begin{abstract}
Light and transmission electron microscopy techniques were used to study different stages of a thraustochytrid, a protist found on the bivalve molluscan Ruditapes decussatus. Vegetative cells developed on the gill epithelium at the base of the cilia. The cells of the protist divide by binary fission giving rise to zoosporangia, each containing 4 uninucleate biflagellated zoospores with a bilateral array of tubular mastigonemes on one of the flagella. Each zoospore develops within a thin nonlaminated wall that is surrounded by a thicker, multilayered zoosporangial wall. Zoospores were ellipsoidal to spherical, $6.1 \pm 0.6 \mu \mathrm{m}$ in diameter. Thraustochytrids have been included in the Kingdom Protoctista and placed in a separate phylum Labyrinthulomycota (= Labyrinthomorpha). Based on the ultrastructural morphology of different developmental stages and absence of sagenogens and ectoplasmic nets, the present microorganism should be included in thraustochytrids. A comparison of ultrastructural observation of the different species in this group provides insufficient data for identifying the species from $R$. decussatus.
\end{abstract}

KEY WORDS: Ultrastructure $\cdot$ Thraustochytrids · Protoctista $\cdot$ Clams

\section{INTRODUCTION}

Several light and electron microscopic studies have been published on species of Labyrinthulomycota (= Labyrinthomorpha) a group of mostly saprotrophic protists, some of which are parasitic on bivalve molluscs (Perkins 1988, Porter 1990). This phylum contains 8 genera, Thraustochytrium, Schizochytrium, Ulkenia, Labyrinthuloides, Labyrinthula, Japonochytrium, Aplanochytriun and Althornia, that have been studied in varying detail (Porter 1990). Overall, however, the phylum is still not well defined (Perkins 1988, 1993, Bower 1987a, Porter 1990). Members of the taxon have been aligned to both algal (Perkins 1974a) and fungal taxa (Perkins 1973b, Alderman et al. 1974, Olive 1975, Lauckner 1983).

Previously, these microorganisms were included in the subkingdom Protozoa and in a phylum, Labyrinthomorpha (Levine et al. 1980). More recently and in order to accommodate this complex group, Porter (1990) established the phylum Labyrinthulomycota (Kingdom Protoctista), which contains a single class (Labyrinthulea), a single order (Labyrinthulida) and 2 families (Labyrinthulidae and Thraustochytriidae). The latter includes 7 genera including the genus Labyrinthuloides. Results of laboratory investigations on the infectivity and pathogenicity of several species of Labyrinthomorpha have been described (Alderman et al. 1974, Bower 1987a, b, c, Whyte et al. 1994), and Bower (1987b) concluded that younger abalone are more susceptible than adults to the abalone pathogen Labyrinthuloides haliotides. On the other hand, thraustochytrids have been reported to be parasitic in molluscan species, such as octopus Eledone cirrhosa (Polglase 1980), squid Illex illecebrosus (Jones \& O'Dor 1983), nudibranch Tritonia diomedea (McLeon \& Porter 1987), and abalone Haliotes hamtschatkana and $H$. rufescens (Bower 1987d). 
The aim of the current work is to describe some ultrastructural details of a previously undescribed thraustochytrid from bivalve molluscs Ruditapes decussatus (Mollusca: Bivalvia) that were simultaneously parasitized with Perkinsus atlanticus (Phylum Apicomplexa, Perkinsidae) (Azevedo 1989, Azevedo et al. 1990). Samples were taken from a population in which mortalities were observed.

\section{MATERIAL AND METHODS}

Fifty living and moribund Ruditapes decussatus parasitized with trophozoites of Perkinsus atlanticus ( 46 of $50,92 \%$ ) were collected in the estuarine region of the 'Ria Formosa', near Faro (Algarve) of southern Portugal from a clam population exhibiting heavy mortalities.

Near the trophozoites of gills infected by Perkinsus atlanticus, different vegetative forms of labyrinthomorphids ( 7 of $50,14 \%$ ) were observed under light microscopy. For transmission electron microscopy (TEM), small fragments of infected gills were collected and fixed in $3 \%$ glutaraldehyde in $0.2 \mathrm{M}$ sodium cacodylate buffer, $\mathrm{pH} 7.6$, for $2 \mathrm{~h}$ at $4^{\circ} \mathrm{C}$, washed for $2 \mathrm{~h}$ at $4^{\circ} \mathrm{C}$ in the same buffer and post-fixed in buffered $2 \%$ osmium tetroxide for $2 \mathrm{~h}$ at the same temperature. After dehydration in a graded ethanol series, the material was embedded in Epon and cut with a diamond knife. Semithin sections were stained in a mixture of methylene blue and Azure II; ultrathin sections were double stained with uranyl acetate and lead citrate, and were observed in a Jeol 100CXII TEM operated at $60 \mathrm{kV}$.

\section{RESULTS}

Several thraustochytrid vegetative cells were observed by light microscopy to be in contact with the cilia of the gill epithelium (Fig. 1). Lysed and disorganized gill epithelial cells, resulting in disruption of the apical surface of the gills, were also observed (Fig. 1). By TEM, the smallest vegetative cells were ovoid to spherical in shape with a diameter of about 4.5 (4.1 to 5.0) $\mu \mathrm{m}(\mathrm{n}=25)$. They contained a single spherical nucleus, several mitochondria, 1 or 2 well-developed
Golgi apparatuses, endoplasmic reticulum and several lipid droplets (Figs. $2 \& 3$ ). Some of these vegetative cells, originating from multinucleate forms, seemed to be engaged in schizogony (Fig. 4). These cells were externally surrounded by a thin wall that seemed composed of several layers of laminated material (Figs. 5 \& 6). After binary fission, a cell wall was formed between the 2 daughter cells (tetrad cell clusters) (Fig. 7). By ultrathin serial sections, it was observed that each zoosporoblast contained 4 zoospores, each one with 2 coiled flagella (Figs. $7 \& 8$ ). Zoospores were ovoid to spherical in shape, approximately $5.3(4.9$ to 5.7 ) $\mu \mathrm{m}$ ( $n=25$ ) wide with 2 inserted flagella (Figs. 7 $\& 8$ ). In favorable ultrathin sections, we observed the mastigonemes attached to the flagella that contained an axoneme with 9 doublet blades pius 2 central microtubules (Fig. 8). The cytoplasm of the zoospores contained several mitochondria and swollen endoplasmic reticulum (Fig. 8). A few free spherical zoospores, approximately $3 \mu \mathrm{m}$ in diameter, were observed among the gill cilia (Figs. $9 \& 10$ ).

\section{DISCUSSION}

While some electron-microscopic studies of labyrinthulids have been published, the taxonomic position of the labyrinthulids is not well established, nor have labyrinthulids been adequately described (revised by Porter 1990). These microorganisms have been included in the kingdom Protoctista and phylum Labyrinthomorpha (Pokorny 1985, Porter 1990). At present, the genus Labyrinthuloides, one of the 8 genera of this group, is represented by only 5 adequately described species: L. yorkensis (Perkins 1973a), L. minuta (Perkins 1974b) (previously Labyrinthula minuta described by Watson \& Raper 1957), L. saliens (Quick 1974a), L. schizochytrops (Quick 1974b) and L. haliotidis (Bower 1987a). The laminated wall of these species varies in thickness depending on the stage in the life cycle and is similar to other less well defined species of the phylum (Alderman et al. 1974, Perkins 1974a, Bower 1987a, Porter 1990). On the basis of the cell shapes and sizes, tetrad cell clusters, laminated wall structures, appearance of the endoplasmic reticulum and tubular mastigonemes, the protist studied here probably belongs to 1 of 2 genera, Labyrinthu-

Figs. 1 to 4. A thraustochytrid from the gill clam Ruditapes decussatus. Fig. 1. Several vegetative cells, adjacent to the gill epithelium $(\mathrm{H})$, with lysis of some host cells $(*) \times 1600$. Fig. 2 . Ultrathin section of 2 vegetative cells showing the nucleus $(\mathbb{N})$, rough endoplasmic reticulum, Golgi apparatus (G), and some mitochondria (M). The cells are externally surrounded by a thin wall (W). $\times 28000$. Fig. 3. A vegetative cell, before karyokinesis, showing a nucleus (N), several mitochondria (M), lipid droplets (L) and the wall (W). $\times 18000$. Fig. 4. A multinucleated vegetative cell with 4 nuclei (N) and the same cytoplasmic organelles as cited in the previous figure. $\times 9000$ 


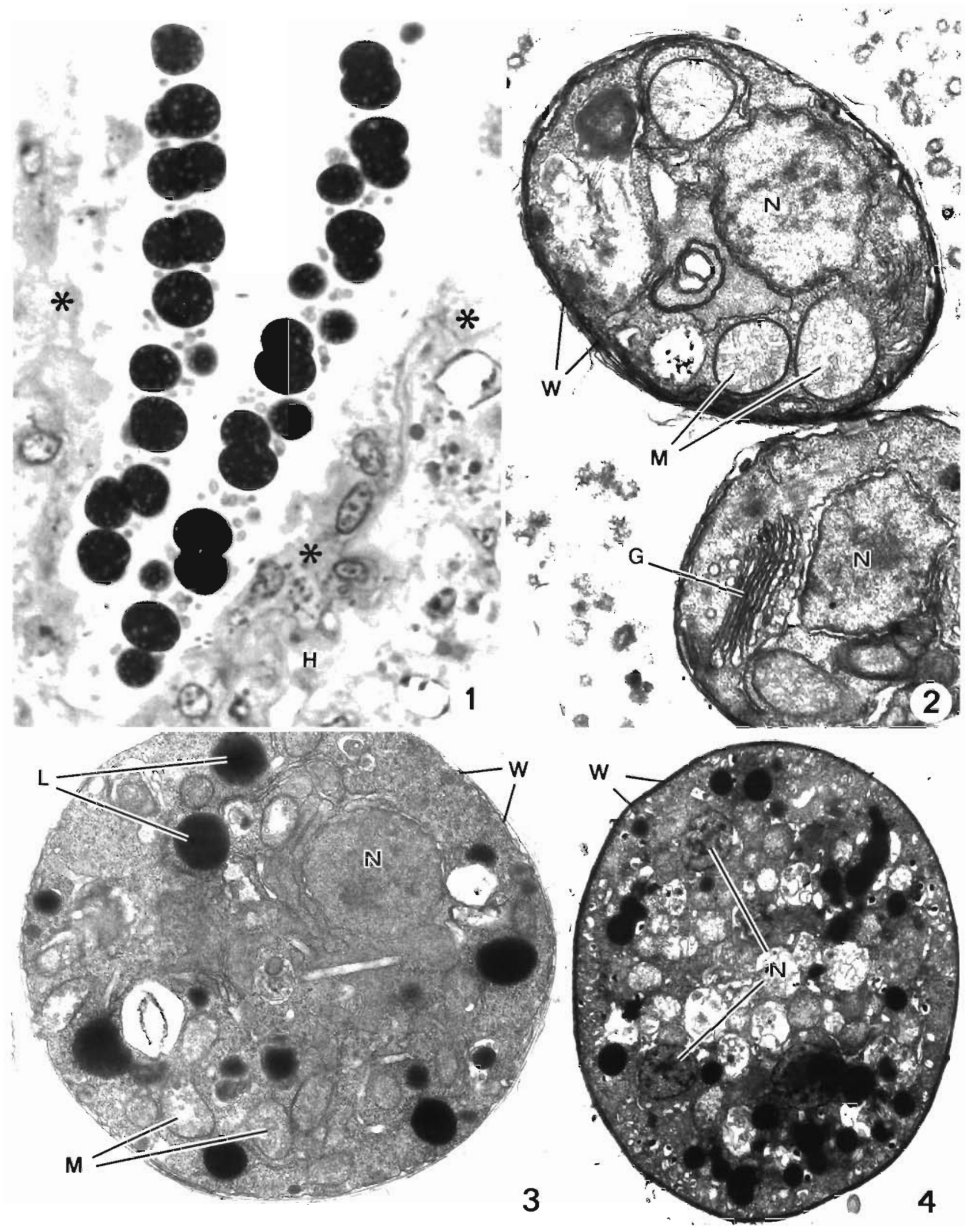



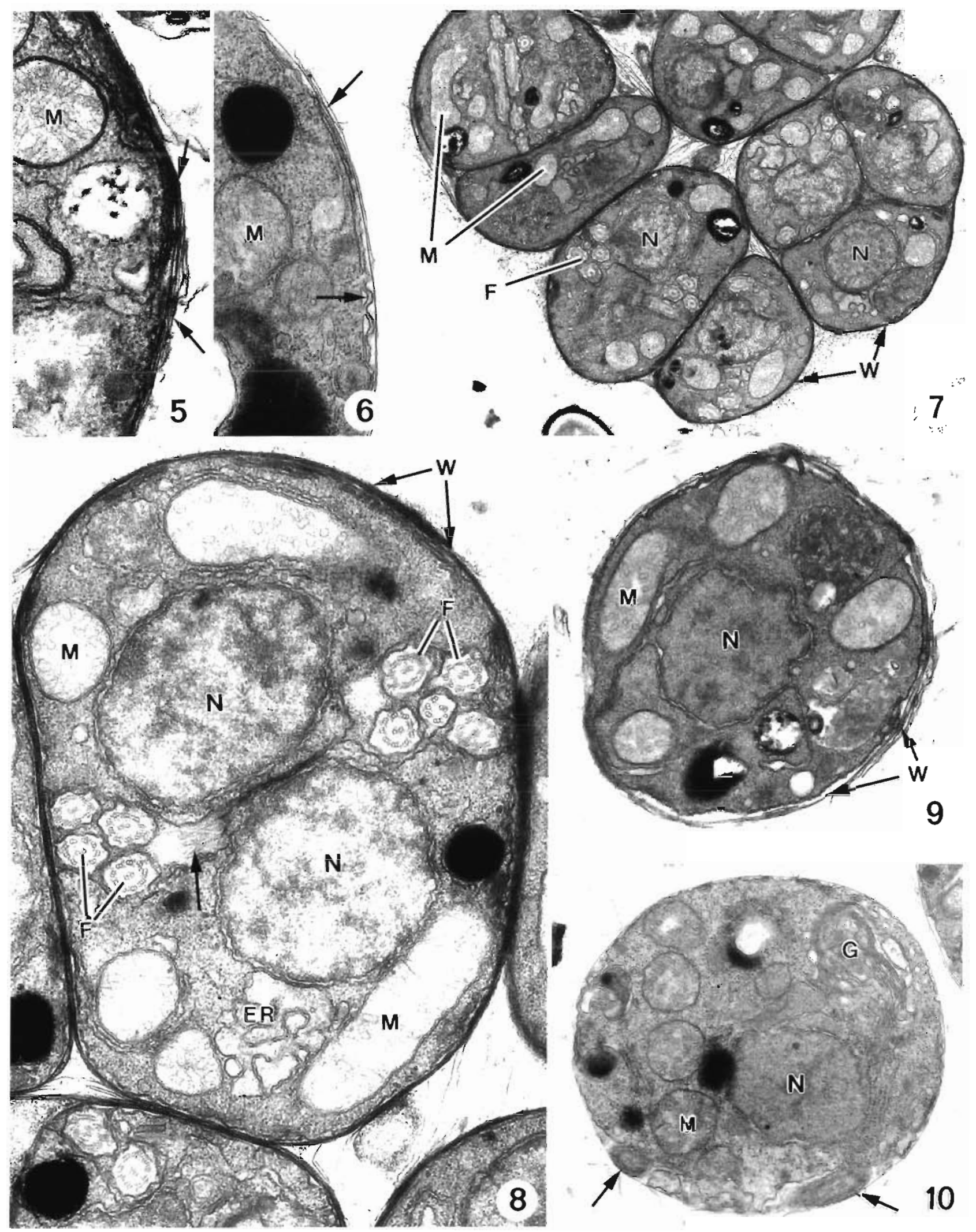
Figs. 5 to 10. A thraustochytrid from the gill clam Ruditapes decussatus. Figs. $5 \& 6$. Details of variations observed in the cell wall (arrows). At the periphery of the cytoplasm the mitochondria $(\mathrm{M})$ are observed. $\times 40900 ; 34870$, respectively. Fig. 7 . Zoosporoblasts containing zoospores associated in groups of 2 and 3 . Each group is surrounded by a wall (W). The nuclei (N), mitochondria (M) and flagella (F) are indicated. $\times 10080$. Fig. 8 . Details of 2 immature zoospores contained within the zoosporoblast. Indicated are the nucleus $(\mathrm{N})$, mitochondria $(\mathrm{M})$, endoplasmic reticulum $(\mathrm{ER})$ and the transverse section of the coiled flagella $(\mathrm{F})$ surrounding the zoospores and the mastigonemes (arrows) which extend from a flagellum. $\times 30460$. Fig. 9. An immature zoospore after liberation from the zoosporoblast, showing the nucleus $(\mathrm{N})$, and some mitochondria $(\mathrm{M})$. At the periphery, the wall (W) is still present. $\times 20630$. Fig. 10. A free zoospore showing some mitochondria (M), Golgi apparatus (G) and the nucleus (N). At the periphery 2 transverse sections of the flagella (arrows) are visible. $\times 20140$

loides or Schizochytrium. However, based on the absence of sagenogens (= sagenogenetosomes) and ectoplasmic nets in our observations we think that it is advisable to consider it a thraustochytrid species, without commitment to a generic designation.

Nothing is known about thraustochytrid species living in European bivalve hosts. This study is only the second one that reports on these microorganisms as parasites of European mollusc hosts; the first was a preliminary ultrastructural report about a presumed thraustochytrid found on the skin of the European lesser octopus Eledone cirrhosa (Polglase 1980). Those ultrastructural data show some similarities with the present results.

Although these organisms are considered as one of the most destructive pathogens of marine bivalves (Polglase 1980, Lauckner 1983, Bower 1987a, b, d), our observations are not adequate for determining whether this thraustochytrid is responsible for mortalities of Ruditapes decussatus which are concurrently parasitized by Perkinsus atlanticus (Azevedo 1989, Azevedo et al. 1990). On the other hand, Perkins (1988) believes that designation as a parasite must be regarded with doubt and the relationship with the host be re-evaluated, as it seems reasonable to consider the protists as facultative parasites. Recently, Whyte et al. (1994) were faced with a similar problem in trying to identify a labyrinthulid found in quahaug clams from a shellfish hatchery in Canada. Further studies are necessary to identify this species of thraustochytrid and determine its host specificity.

Acknowledgements. This work was partially supported by the Science Program for EEC, and the A. Almeida Foundation (Porto, Portugal). We thank Mr J. Carvalheiro for technical assistance.

\section{LITERATURE CITED}

Alderman DJ, Harrison JL, Bremer GB, Jones EBG (1974) Taxonomic revisions in the marine biflagellate fungi: the ultrastructural evidence. Mar Biol 25:345-357

Azevedo C (1989) Fine structure of Perkinsus atlanticus n. sp. (Apicomplexa, Perkinsea) parasite of the clam Ruditapes decussatus from Portugal. J Parasitol 75:627-635
Azevedo C, Corral L, Cachola R (1990) Fine structure of zoosporulation in Perkinsus atlanticus (Apicomplexa, Perkinsea). Parasitol 100:351-358

Bower SM (1987a) Labyrinthuloides haliotidis n. sp. (Protozoa: Labyrinthomorphaj, a pathogenic parasite of small juvenile abalone in a British Columbia mariculture facility. Can J Zool 65:1996-2007

Bower SM (1987b) Pathogenicity and host specificity of Labyrinthuloides haliotidis (Protozoa: Labyrinthomorpha), a parasite of juvenile abalone. Can J Zool 65:2008-2012

Bower SM (1987c) Artificial culture Labyrinthuloides haliotidis (Protozoa: Labyrinthomorpha), a pathogenic parasite of abalone. Can J Zool 65:2013-2020

Bower SM (1987d) The life cycle and ultrastructure of a new species of thraustochytrid (Protozoa: Labyrinthomorpha) pathogenic to small abalone. Aquaculture 67:269-272

Jones GM, O'Dor RK (1983) Ultrastructural observations on a thraustochytrid fungus parasitic in the gills of squid (Illex illecebrosus Lesueur). J Parasitol 69:903-911

Lauckner G (1983) Diseases of Mollusca: Bivalvia. In: Kinne O (ed) Diseases of marine animals, Vol II. Biologische Anstalt Helgoland, Hamburg, p 477-961

McLeon N, Porter D (1987) Lesions produced by a thraustochytrid in Tritonia diomedea (Mollusca: Gastropoda: Nudibranchia). J Invertebr Pathol 49:223-225

Levine ND, Corliss JO, Cox FEG, Deroux G, Grain J, Honigberg BM, Leedale GF, Loeblich AR III, Lom J, Lynn D, Merinfeld EG, Page FC, Poljansky G, Sprague V, Vavra J, Wallace FG (1980) A newly revised classification of the Protozoa. J Protozool 27:37-58

Olive LS (1975) The Mycetozoans. Chap. 7. Labyrinthulina (Labyrinthulas and Thraustochytrids). Academic Press, New York, p 215-281

Perkins FO (1973a) A new species of marine labyrinthulid Labyrinthuloides yorkensis n. gen., n. sp.-cytology and fine structure. Arch Mikrobiol 90:1-17

Perkins FO (1973b) Observations of thraustochytriaceous (Phycomycetes) and labyrinthulid (Rhizopodea) ectoplasmic nets on natural and artificial substrates-an electron microscope study. Can J Bot 51:485-491

Perkins FO (1974a) Phylogenetic considerations of the problematic thraustochytriaceous - labyrinthulid-Dermocystidium complex based on observations of fine structure. Veröff Inst Meeresforsch Bremerhaven Suppl 5:45-63

Perkins FO (1974b) Reassignments of Labyrinthula minuta to the genus Labyrinthuloides. Mycologia 66:697-702

Perkins FO (1988) Parasite morphology, strategy, and evolution. Structure of protistan parasites found in bivalve molluscs. In: Fisher WS (ed) Disease processes in marine bivalve molluscs. American Fisheries Society Spec Publ 18, Bethesda, p 93-111

Perkins FO (1993) Infectious diseases of molluscs. In: Couch JA, Fournie JW (eds) Pathobiology of marine and estuarine organisms. CRC Press, London, p 255-287 
Pokorny KS (1985) Phylum Labyrinthomorpha. In: Lee JJ, Hunter SH, Bovee EC (eds) An illustrated guide to the protozoa. Soc Protozoologists, Lawrence, KS, p 318-321

Polglase JL (1980) A preliminary report on the Thraustochytrid(s) and Labyrinthulid(s) associated with a pathological condition in the lesser octopus Eledone cirrhosa. Bot Mar XXIII:699-706

Porter D (1990) Phylum Labyrinthulomycota. In: Margulis L, Corliss JO, Melkonian U, Chapman DJ (eds) Handbook of Protoctista. Jones and Bartlett Publ, Boston, p $388-398$

Editorial responsibility: Albert Sparks,

Seattle, Washington, USA
Quick JA (1974a) A new marine Labyrinthula with unusual locomotion. Trans Am Microsc Soc 93:52-61

Quick JA (1974b) Labyrinthuloides schizochytrops n. sp., a new marine labyrinthula with spheroid 'spindle' cells. Trans Am Microsc Soc 93:344-365

Watson SW, Raper KB (1957) Labyrinthula minuta sp. nov. J Gen Microbiol 17:368-377

Whyte SK, Cawthorn RJ, McGladdery SE (1994) QPX (Quahaug Parasite X), a pathogen of northern quahaug Mercenaria mercenaria from the Gulf of St. Lawrence, Canada. Dis Aquat Org 19:129-136

Submitted: March 20,1996, Accepted: June 25, 1997 Proofs received from author(s): September 16, 1997 